International Journal of Social Science and Economic Research

ISSN: 2455-8834

Volume:05, Issue:08 "August 2020"

\title{
JUDGES AS TEACHERS
}

\author{
Haddy Roche \\ Haddy Roche is a judge of The Gambia Court of Appeal
}

DOI: 10.46609/IJSSER.2020.v05i08.010 URL: https://doi.org/10.46609/IJSSER.2020.v05i08.010

\begin{abstract}
Judges are fundamentally teachers. But their teaching role is often obscured and muted. This discussion aims to give prominence to the teaching role of judges. It demonstrates that judges teach when they exercise judicial power generally, and specifically when they respect the principle of precedent, and observe high standards of behavior. It highlights that, though the teaching role of judges is significant for confirming judges' connection to society, for keeping the law alive and responsive to the needs of society, for spotlighting the utility of judges, for keeping judges motivated, for engendering greater judicial efficiency, positive perception of judges, and access to justice, it is hardly singled out for extended discussion and appreciation, and hence, the misperception and under appreciation of judges, and dissatisfaction with the administration of justice. It recommends broadening judicial training content to guide judges use this role constructively, but it also recognizes other significant hurdles to overcome if judges are to perform this role constructively.
\end{abstract}

Keywords: Judge, role of judges, teaching role of judges, judicial efficiency, access to justice, administration of justice

\section{INTRODUCTION}

We are all teachers, Schwehn (2000) tells us. However, there are some, such as the judges amongst us, who hold positions of responsibility that oblige them to teach, despite that they are not professionally trained teachers. Judges have duties that oblige them to serve as teachers, so they are teachers, and have a teaching role. However, because their teaching role is hardly explored and hardly publicized, there is little public awareness of it. Lack of public awareness about the judge's role, in particular a significant role such as the judge's teaching role, means that judges can be misperceived, underappreciated, and unfairly attacked. 


\section{International Journal of Social Science and Economic Research}

ISSN: $2455-8834$

Volume:05, Issue:08 "August 2020"

Kirby (1998) blamed lack of information about the judge's role for the "universal phenomenon" (para. 1) of attacks on judges, and the extensive erosion of the deference normally shown to judges. He recommended educating the public, to nurture more informed appreciation of judges. Lack of information about the judge's role inevitably leads to negative perception of judges. Gloppen (2013), reports a worldwide phenomenon of negative perception of judges. The present discussion is therefore long overdue, and is part of efforts to educate the public about the role of judges, and to encourage a positive perception of judges. Because it emphasizes the usefulness of judges, it can also be a magnet for drawing people into the judging profession, as well as motivate serving judges to remain committed.

Over hundred years ago, Pound (1906) informed us that "dissatisfaction with the administration of justice is as old as the law" (pg.1). While Stein (2007) observes that dissatisfaction with the administration of justice as observed by Pound (1906) persists in the United States, a United Nations Development Program Practice Note On Access to Justice (2015), highlights that dissatisfaction with the administration of justice, is still very much alive and kicking, persists globally, and shows little signs of dying. It underscores lack of adequate public information and limited knowledge about rights, court processes, and court officials entrusted to ensure access to justice, as major barriers to access to justice and efficient justice systems. Under the circumstances, the search for solutions must continue, and so there is clearly a need for discussions such as the present, for they can contain useful information that can be helpful to the search for solutions.

Judges are inextricably connected to the public. The public need them for the order, security, and the peace of mind they can ensure, they are appointed on behalf of the public, to serve the public. They need public trust and confidence. The laws they interpret and apply are made for the public- to respond to the needs and interests of the public (Cardozo, 1939; Clark \&Trubek, 1901; Ehrlich, 1903\&1975; Frank, 1930; Pound, 1930). It is therefore in the public interest to have discussions such as the present, for they have the potential to inspire ideas for greater judicial efficiency, which according to a World Bank study by Botero et al (2013); Gloppen (2013); and Logan (2017), is lacking in many countries around the world.

My discourse takes a general form, mainly because studies such as that by Armytage (2015), indicate a general desire to improve the efficiency of judges and justice systems. And the same studies by Botero et al (2015); Gloppen (2013); and Logan (2017) make it clear, that although disaffection with the judicial sector is often more pronounced and more intense in developing countries, it is nonetheless a universal phenomenon generally experienced across the world. 


\section{International Journal of Social Science and Economic Research}

ISSN: $2455-8834$

Volume:05, Issue:08 "August 2020"

Although where possible, reference is made to specific state of affairs in The Gambia to provide concrete examples closer to home, this is a study heavily reliant on foreign literature. It is an account premised on what generally operates in the common law systems-the systems based on the English legal tradition (which is what operates in The Gambia, a former colony of Britain and a beneficiary of the English Legal tradition), as opposed to the civil law systems, which have their roots in Roman law (Tetley, 2000). It was underscored by Allot (1968), that a central fact about the general legal systems of African countries, is that they are derived wholly or partly from the legal systems of their former colonial powers. The Gambia is no exception.

In The Gambia, the roles of judges are recognized by statute- The Judges Act (2009). These roles include the role to be independent, impartial, fair, ethical, courteous, and professional. These roles are essentially and fundamentally teaching roles, but they are not expressly recognized as teaching roles. It is my contention that because they are all fundamentally teaching roles, they confirm that judges essentially have one major role- a teaching role. Nevertheless, sections 15 (2), (3), and 18(1) of the same Act expressly recognizes the teaching role of judges outside formal court proceedings. Section 15(2) provides:

A Judge must devote his or her professional activity to judicial duties broadly defined, which include, not only presiding in court and making decisions, but also other judicial tasks essential to the operation of the court

Section 15(3) provides:

A Judge must take reasonable steps to maintain and enhance the knowledge, skills and personal qualities necessary for judicial office

Section 18(1) provides:

A judge may, to the extent that time permits and subject to the limitations imposed on his of her judicial office, contribute to the administration of justice by, for example, taking part- (a)In continuing legal education programmes for judges and legal practitioners; and

(b)In activities that make the law and the legal process more understandable and accessible to the public

Despite the express and clear statutory recognition of the judge's teaching role, there is no local literature on the topic.

\section{SIGNIFICANCE OF THE STUDY}




\section{International Journal of Social Science and Economic Research}

ISSN: $2455-8834$

Volume:05, Issue:08 "August 2020"

Section 18(1) of the Judges Act as reproduced, clearly and expressly sanctions the present study. It is therefore one way of making good use of the said section to contribute to the better administration of justice. Furthermore, Logan's (2017) account of the findings by Afrobarometer, suggests that Africans generally have little faith in their justice systems. The inquiry can therefore contribute to efforts aimed at encouraging Africans to develop faith in their justice systems. Admittedly, in African countries where the illiteracy and poverty rates are high, a significant number of the population might not be disposed to follow court proceedings, let alone learn from them to appreciate the teaching role of judges. Nevertheless, according to the same account by Logan (2017), such members of the population are more vulnerable to injustice, and are more likely to suffer injustice than others. Therefore, they deserve to be sensitized about the justice system. Indeed, because they are more vulnerable to injustice, they should pay attention to the justice system, so that they know how to take advantage of it to protect themselves, and to get the results they want. Also, the United Nations Development Goal 16, implores societies to provide access to justice for all, and to build effective, accountable, and inclusive institutions at all levels including the judiciary. Studies such as the present, can therefore be part of efforts being made to answer this imploration.

Most, if not all, of the available literature on the role of judges is foreign and Western, which should not be surprising, because developing countries borrow from Western systems. However, there is hardly much Western literature specifically on the teaching role of judges. Under the circumstances, there is need to develop both the local and Western literature on this important role. The full extent of the judge's role must be discussed and understood, to ensure proper appreciation of judges, and public confidence in the administration of justice.

When judges exercise their powers properly, and adequately explain their decisions, are independent, impartial, fair, ethical, professional, and do what society expects them to do, they impart valuable knowledge, set standards, and nurture the same behavior in others. They encourage critical thinking, self-reflection, and imagination. They inform behavior, form minds, characters, habits and way of life, in the same way Schwehn (2000) suggests teachers do.

Flango et al (1975) describe judges as "perhaps the most role conscious of all officials" (p.277). However, because the bulk of the available literature mutes their teaching role, they might actually be less mindful of this role, and so less likely be inclined to perform it as effectively as they would wish. If much attention is not paid to this role, there would be less motivation for judges to make it prominent, and perform it to the best of their ability. Hanson 


\section{International Journal of Social Science and Economic Research}

ISSN: $2455-8834$

Volume:05, Issue:08 "August 2020"

(2002) for example, discuss studies about different judicial role orientations (the different roles judges expect they should perform), and among the judicial role orientations identified in his study are: "The Law Interpreter"- the judge who emphasizes judicial restraint; "The Adjudicator"the judge who emphasizes concern for social consequences of decisions; "The Law Applier'the judge who emphasizes precedent and individual litigants; and "The Law Extender"-the judge who emphasizes precedent and the public. However, "The Teacher" -the judge who emphasizes concern for public enlightenment and setting credible standards for public behavior, is missing from the judicial role orientations, despite that it is inherent in and underlies the other role orientations discussed.

Studies by Scheb et al (1989) and Flango et al (1975), also explain how judicial role orientations impact judicial decisions. Although they offer valuable insight, they mute the teaching role of judges. The teaching role of judges is also not specifically recognized and addressed in Posner's (2006) discussion about concepts of the judicial role. Nava (2008), and Resnik (1988) extensively explain the aspirations we should have for our judges, the humanity in judging, and the human qualities inherent in the act of judging, but they do not single out and emphasize the teaching aspect of judging. Baum (1994) and Epstein (2017) discuss judicial goals and how they impact judicial decisions. However, their list of goals does not include a teaching goal. Studies about essential judicial virtues, such as by Solum (1988), are instructive, yet do not associate the teaching aspect of judging to the judicial virtues they identify.

Appraisals of theories of judicial decision making such, as by Capurso (1998), do not include theories that advance how judicial decisions are impacted by the teaching role of judges. Insights on the impartial role of the judge in governance and democracy such as by Lord Devlin in Devlin (1976,1979); Barak (2002); and Kapiszewski et al (2013), are all educative, but also mute the teaching role of judges. Judges' concerns about institutional legitimacy, legality, and policy as discussed by Epstein \& Knight (2017), and discussions about judges' law making role, such as that by Lord Reid in Reid (1972), amply demonstrates judges' potential and capacity to teach, but this is not singled out as a subject of discussion. Clearly, there is a huge gap in the literature, and the present study will add to efforts to fill this gap.

In fact, what should be emphasized, is that the teaching role of judges is very glaring and obvious in all of the above literature. Therefore, the learned authors are very much aware of it. Because the teaching role of judges can be obvious, it is generally taken for granted and often muted. Nevertheless, discussions such as the present are necessary, because the teaching role 


\section{International Journal of Social Science and Economic Research}

ISSN: $2455-8834$

Volume:05, Issue:08 "August 2020"

of judges is not always obvious to everyone. Moreover, the teaching role of judges can be demonstrated and made obvious in other ways than the ways generally portrayed in the existing literature.

The teaching role of judges is just too significant to be taken for granted and muted even if it is obvious to some. Despite that this role can be obvious, it still needs to be continuously discussed and given prominence if judges are to be motivated to continue to perform it effectively, and if judges are to be properly and sufficiently appreciated. If judges do not effectively perform their teaching role, and if there is no sufficient appreciation of their teaching role, then the full extent of their usefulness will not be appreciated. If the full extent of their usefulness is not appreciated, there cannot be satisfaction with the administration of justice. Conners (2015) however suggests that the usefulness of judges, in particular their ability to transform and save lives, must be promoted and made prominent, especially to judges themselves, for it can motivate them to perform even better. The better the judges perform, the lesser the dissatisfaction with the administration of justice.

\section{CAVEAT}

A study on the teaching role of judges should not deflect from the equally important fact that judges are, or should be learners. In the case of The Gambia, sections 15(2), (3) and 18(1) of the Judges Act (2009) makes the judge both a teacher and a learner. In fact, Armytage (2015) emphasizes that there is a high demand for judicial education stemming primarily from the desire by judiciaries across the world to improve their competence. He explained that:

Recognition of the need for judicial education is now firmly established in many jurisdictions around the world. The reasons for the emergence of judicial education are multifold. Prominent among these are the need perceived by the judiciary to professionalize, in large part improving competence, the need for the judiciary to provide a visible means of social accountability to address mounting consumer dissatisfaction with judicial services (p. 20).

Goldbach (2016) informs us that the World Bank spends approximately U.S.\$24 million per year on improving court performance globally. And the World Bank study by Botero et al (2003), underscores that judicial inefficiency plagues many countries- in particular developing countries. The study blames inadequate judicial training as one of the causes of inefficiency. 


\section{International Journal of Social Science and Economic Research}

ISSN: $2455-8834$

Volume:05, Issue:08 "August 2020"

Judges must therefore be open to learning. However, they must not only be open to learning, they must be open to learning broadly. This was underscored by Ray (2010) when he advised some American judges thus:

Learned Hand wrote that the excellence of a judge comes not simply from his or her knowledge of law, but also from the wisdom and understanding drawn from history, philosophy and everything you study. We need you to be broadly educated and not just from books. You will be interpreting different cultures, different human actions and evaluating people acting under stress. Every experience in your life enhances your capacity to judge and we need you to continue to be learners (p. 25)

Judges certainly learn from lawyers. As Barton (2007) puts it:

A closer examination of the nuts and bolts of a judge's job also demonstrates how critical lawyers are to the work of judging. In the advocacy system most judges rely on the lawyers to do the great bulk of work in trying, briefing, researching, or investigating cases. When the system is working properly the judges sit back and decide cases based on the legal and factual work of the lawyers (n.p.).

Judges are informed and aided by lawyers who articulate relevant arguments, cite relevant authorities, identify relevant legal issues, and engage in sophisticated legal analysis (Robbins, 2002). But the learning from lawyers go beyond legal issues. Judges will have to study the personality of lawyers who appear before them. This enables them develop the appropriate responses to maintain professionalism and order in the courtroom. This means that lawyers also help judges learn to develop other valuable teaching attributes such as humility and restraint, which confirms that judicial restraint and humility is not only inspired or informed by the principle of precedent, which is addressed later in this discussion.

Judges learn from litigants too. They deal with different types of litigants and cases. They have the opportunity to learn different aspects of human behavior, problems, and circumstances.

\section{WHY JUDGES ARE TEACHERS}

I am well aware, that judges actually teach legal subjects in formal educational institutions, give public lectures, and make presentations in workshops and conferences. In The Gambia, for example, some judges teach at the Law School and give public lectures. These are activities outside formal court proceedings. However, this study concerns mainly the teaching role of judges as they preside over court matters. That notwithstanding, I subscribe to a broad and 
International Journal of Social Science and Economic Research

ISSN: 2455-8834

Volume:05, Issue:08 "August 2020"

holistic definition of the term "teaching". Therefore, I subscribe to Schwehn's (2000) insightful observation that everyone is a teacher, and I favor Smith's (2019), definition of teaching as "the process of attending to people's needs, experiences and feelings, and intervening so that they learn particular things, and go beyond the given" (para.1). And I also subscribe to the view, that teachers educate, inspire, learn, and effect change to make a positive difference (Teach.Com, n.d.).

In a detailed study, Bartlett (2010) aptly captures the similarities between the judging and teaching professions as follows:

...the public professions of teacher and judge are strikingly similar. Both are charged with a duty to act as neutral, objective figures in order to normalize and examine individual subjects for the public good. In each profession, contemporary tensions between competing desires are located at the site of examination. Indeed, a trial is defined by the most widely used legal dictionary as '[a] formal judicial examination of evidence' (Garner, 2004)... (p. $1)$.

All the similarities between the two professions identified in Bartlett's (2010) study, can be summed up as follows:

i. Both work in the public domain, and in publicly accessible work space

ii. Both are perceived as powerful leaders due to powers they have over their subjects

iii. Both have public trust because they are perceived as neutral

iv. Both must act within defined codes of conduct

v. Both mold their subjects and have the final say over their subjects

vi. Both are judgmental because they measure, report, and mark their subjects through a process of examination or evaluation

To Bartlett's (2010) list, I will add, that both can transform their subjects for the better, and so both can save the lives of their subjects. Also, both are expected to protect their subjects, and because they are expected to protect their subjects, they can help towards the establishment of a culture of safety, and the maintenance of the emotional wellbeing of their subjects.

Ray (2010), in advising American judges, also demonstrated what makes the judge a teacher when he said:

You have the opportunity to teach in may settings. In the hearing room, you explain the process to the unrepresented and to others who do not know how it works. In your written 
International Journal of Social Science and Economic Research

ISSN: 2455-8834

Volume:05, Issue:08 "August 2020"

decision, you teach us by giving us a blueprint to guide our future actions. In the outside world, you wrote articles, you teach at law schools and you speak at conferences. You know your areas of law better than anyone. You have learned better than anyone what constitutes good advocacy by evaluating the hundreds or thousands of advocates who have appeared before you. Because of the credibility you have and the awe we have for judges, lessons learned from a judge are remembered. Most importantly, you host schoolchildren in your courtrooms and you visit junior high schools and high schools to share your expertise. You are the face of our justice system to them and you represent us well. (p. 25)

Uspanov\&Turabayeva (2016) also explained that:

Each judge is an educator, [of] a significant number of people. An experienced judge is distinguished by high responsibility for their actions, for their decisions, integrity. The judge is constantly in the focus of all trial participants. All of his comments and gestures are subject to constant monitoring and evaluation...

...Each sentence of the court should have educational impact that will be achieved only if the audience correctly understands the sentence, if it meets their moral conviction and corresponds to the circumstances of the case (p. 5855).

What is however missing from the above literature, is an extended and in depth examination of the teaching role of judges.

\section{HOW JUDGES TEACH}

Having established that judges are teachers, I will now demonstrate how they teach in three interrelated situations: when they exercise judicial power generally, and specifically when they respect the principle of precedent, and observe high standards of behavior.

\section{i. EXERCISE OF JUDICIAL POWER}

\section{Definition and origin}

Judicial power is defined in Black's Law Dictionary (1968), as the "authority exercised by that department of government which is charged with declaration of what law is and its construction" (p. 986). Judicial power can be expressly vested in courts by national constitutions. For example, it is vested by the 1997 Constitution of The Gambia, and it is vested by the constitutions of many other countries including those of Ghana, Kenya, United States of America, and South Africa. In the case of The Gambia, the relevant constitutional 


\section{International Journal of Social Science and Economic Research}

ISSN: $2455-8834$

Volume:05, Issue:08 "August 2020"

provision is section 120 (2) of the 1997 Constitution, which provides that the "judicial power of The Gambia is vested in the courts and shall be exercised by them according to the respective jurisdictions conferred on them by law".

However, judges cannot exercise judicial power over matters they do not have jurisdiction to determine. In the Gambia, the jurisdiction of each court is set out in the said Constitution, which places the Supreme Court at the Apex position, followed by the Court of Appeal, the High Court, Magistrates' Court, and other subordinate courts (see sections 120, 126, 127, 128, $130,132,133,135$ thereof). Under the circumstances, judicial power can simply be defined as the power judges have in respect of matters over which they have jurisdiction. It is essentially the power to hear a case or matter, and render a decision in the form of an order or judgment.

The concept of judicial power emanated from the principle of separation of powers-that government power should be separated into three branches: executive, legislative, and judicial. While judicial power lies with the courts-the judicial branch, executive and legislative powers lie with the executive and legislative branches respectively. Pound (1922) succinctly explained the origin of the principle in the following:

The theory that the powers of government should be divided into the three classes indicated, to the end that in state and nation we may live under a government of laws rather than men, is confidently said to have been suggested by Aristotle, developed by Montesquieu and adopted wherever constitutional governments are found. The maxim that the protection of the rights of persons from the evils of despotic forms of government requires the complete separation of governmental powers...Rights rest for their substantial basis on the guarantees of life, liberty and property. The protection of rights causes the division of powers; the division does not create the rights. The separation of powers provides the formidable sanction and the useful working rule of convenience for the maintenance of rights, but it is coupled with all the checks and balances which have been devised to prevent any department of government from exercising its functions without interference from or responsibility to the other departments (p. 788).

Judicial power then serves as a check on the other branches of government, as well as on private individuals. It is exercised in cases brought by or against other branches of government, as well as in cases against and between private individuals.

\section{The teaching aspect}




\section{International Journal of Social Science and Economic Research}

ISSN: $2455-8834$

Volume:05, Issue:08 "August 2020"

Unless a case is heard in camera (held privately before a judge), the judge will hear it in public, and will deliver the judgment in public. In the case of The Gambia, this is a constitutional requirement. Section 24(2) of the 1997 Constitution provides that:

All proceedings of every court and proceedings relating to the determination of the existence of or extent of civil rights or obligations before any other authority including the announcement of the decision of the court or authority, shall be held in public...

Therefore, court proceedings are generally open and transparent, and the public will be able to, and is allowed to scrutinize all aspects of it. In the words of Lord Atkin in Ambard v Attorney General for Trinidad and Tobago (1936):

...no wrong is committed by any member of the public who exercises the ordinary right of criticizing in good faith in private or public the act done in the seat of justice. The path of criticism is a public way... Justice is not a cloistered virtue: she must be allowed to suffer the scrutiny and respectful...comments of ordinary men (n.p. 23).

The media in particular, has access to the proceedings, and will serve as the link between the court and members of the public who are not present. The media transmits information (lessons) from the court to the public and vice versa (McLachlin, 2012). Hence, a professional media, and a healthy relationship between judges and the media are crucial to the teaching role judges. Ignorant, inaccurate, and sensational media reports of judicial proceedings often occur (Basten, 2012; Pound, 1906), and they can portray the judge as an ignorant amateur, rather than a valuable teacher.

The judge presides over the proceedings, and assumes the position of a teacher: the judge observes the parties, engages the parties, listens to what the parties and their witnesses have to say, receive any evidence the parties wish to produce, and then engage in evaluation of the facts and evidence. The judge then grades the parties using the burden and standard of proof required by the law as bench mark. In civil cases, the plaintiff has the burden of proving their case on the balance of probabilities (Miller v Minister of Pensions (1947)), while in criminal cases, the prosecution has the burden of proving their case beyond reasonable doubt (Woolmington $v$ DPP (1935)). If the party with the burden of proof discharges same to the standard required by law, they will be graded highly, and judgment will be entered in their favor.

In the judgment, the judge will identify the applicable law, explain how it applies to the case, and why a party deserves favorable judgment and the other party does not. The judge must 


\section{International Journal of Social Science and Economic Research}

ISSN: $2455-8834$

Volume:05, Issue:08 "August 2020"

give reasons for the judgment. There are those in the civil law system, such as van den Herik (1991) as cited by Nakad-Westrate et al (2015), who predict that judicial reasoning will eventually be done by computers together with or instead of human judges, and those in the common law system such as (D'Amato, 1977), who see some value in computers replacing human judges. However, the duty on human judges to give reasons is particularly useful for their teaching role, because it is what explains and rationalizes their decision to litigants and the public, as well as sets the standards for the future. Cohen (2015) justifies the judge's duty to give reasons as follows:

Judicial reason-giving is fundamental to a democratic regime because free and equal citizens should be treated not merely as objects of rule application and rule making but also as autonomous agents who take part in making the law of their own society...Being subject to judicial authority that is unreasoned is to be treated a mere object of the law or of political power, not a subject with independent rational capacities. In other words, reason-giving treats parties and the general public as rational moral agents who are entitled to evaluate and sometimes to participate in judicial decisions (p. 505).

The obligation on judges to give reasons, ensures transparency in the process because it ensures the parties know how the judgment was reached. It ensures fairness, and allows the parties the opportunity to determine the soundness of the judgment, and how to proceed from the judgment. As explained by Henry LJ in Flannery v Halifax Estate Agencies Ltd [2000]:

The duty is a function of due process, and therefore of justice. Its rational has two principal aspects. First is that fairness surely requires that the parties-especially the losing partyshould be left in no doubt why they have won or lost. This is especially so since without reasons the losing party will not know... whether the Court has misdirected itself and thus whether he may have an available appeal on the substance of the case. The second is that a requirement to give reasons concentrates the mind; if it is fulfilled, the resulting decision is much more likely to be soundly based on the evidence than if it is not (n.p.).

See also the case of English v Emery Reimbold\&Strick Ltd [2002] on the same point. However, the judgement must not only be reasoned-it must be adequately reasoned, and must respond to relevant issues raised if it is to serve a meaningful educative purpose. Otherwise, it can be dismissed on appeal, as was the case in Simetra Global Assets Ltd \&Anor $v$ IkonFinanace Ltd \&ors (2019). 


\section{International Journal of Social Science and Economic Research}

ISSN: $2455-8834$

Volume:05, Issue:08 "August 2020"

The obligation to give reasons not only allows judges to maintain their intellectual integrity, it also allows lawyers, litigants and the public to be intellectually stimulated, because the reasons will inevitably be analyzed and critiqued. Because the judgment is analyzed, critiqued and graded by the public, or on appeal, it also puts judges in the position of the learners. Indeed, the judgment being a "conclusion that naturally follows from the premises of law and fact" (Black's Law Dictionary 1968, p. 977), will be guided and informed by the law and the evidence. This is another indication that the judgment also puts judges in the position of learners.

Significantly, because judges in their judgments, can scold lawyers for incompetent research and writing (Whisner, 2004), they inevitably train lawyers -especially junior lawyers, to be efficient and professional. Judges with high standards will inspire lawyers to expect high standards. They will also inspire the public to expect high standards, and as a result help inculcate and establish a culture of high judicial standards.

\section{Significance of the Judgment}

Apart from guiding litigants and their lawyers, the reasons in the judgment will also guide and inform the public's future actions- they serve as blue print for the future actions of the public (Ray, 2010). The reasons in the judgment can provide the necessary information and understanding that allows closure and peace of mind for a litigant. The fact is, not all losing litigants are bitter, and disgruntled. Consequently, some litigants who are informed and enlightened by a judgment, will accept the judgment even if it is unfavorable to them. Some litigants resort to the courts, not because they are litigious, but because they want to be sure, and want to hear from an authority such as a court, as to where responsibility lies. Therefore, as soon as the court makes a decision, and forwards reasons that resonates with them, they will accept the decision and put the matter to rest, even if the decision is against them and they are inconvenienced by it. The reasoning in the judgment adequately sensitizes and satisfies such litigants, and motivates them to put the matter to rest, rather than appealing to the higher courts and adding to the backlog of cases in those courts.

In fact, the reasons in a judgment can provide sufficient information and enlightenment to guide a potential litigant take the necessary steps to settle a matter peacefully out of court. For example, a judgment in a case about damages for breach of contract, might clearly list actions that would constitute a breach of contract and actions that would not. Such actions listed in the judgment, can inform, guide, and convince potential litigants in a similar case, to reach peaceful settlement out of court without proceeding to court and adding to the backlog of 


\section{International Journal of Social Science and Economic Research}

ISSN: $2455-8834$

Volume:05, Issue:08 "August 2020"

cases. This suggests that the reasons in a judgment can serve as peace teacher and a peace builder.

A judgment is often about issues that matter to the community. Such issues include marriage, divorce, environmental protection, crime, sexual violence, women's rights, discrimination, children's rights, religious rights, traffic matters, and business relations among many other issues. It determines what is or is not acceptable behavior to the community, and so offers lessons about the values of the community, and reinforces the values of the community. As contended by Law (2009), people cannot recognize or respond to bad behavior if they are unaware of it. The judgment provides the necessary information for people to be aware of bad behavior in the community, and to be able to respond to bad behavior in the community. When the judgement is in respect of a prevalent crime or issue, not only will there be an interest to determine its soundness, there will also be an interest to determine if it offers a good solution. If it is sound and offers a good solution, it will inspire faith in the law and in the justice system as a whole.

A judgment can impose sanctions, and any sanction imposed sends a message, and informs that certain behavior is wrong and will not be tolerated. It can serve as deterrence, and such deterrence can teach self- restraint, discipline, and humility. Sometimes, the impact of a stiff fine or sentence in a criminal case, or punitive damages in a civil case, will serve as a valuable teacher and deterrence. But a sanction in the judgment, can also provide the offender with the time and opportunity to reflect on the gravity of their actions, and to learn from their actions. A sanction of imprisonment, however short the term, can provide an offender the time and opportunity to reflect, learn, repent, and reform. Martin (2020) reports about a violent offender, who was thankful to a judge for placing him on remand, because that gave him the time he needed to reflect, and to appreciate the severity of his violence and alcoholism.

Specialty Courts in the United States, also known as Problem Solving Courts, are courts that give offenders opportunity to learn from their mistakes and lead better lives. According to Frailing (2016), these courts became part of the American court system in the late 1980s, and they mostly take charge of a case after the offender pleads guilty and is to be sentenced or is placed on probation, and only if the offender agrees to participate in the proceedings. Judges preside over proceedings, which are not aimed at punishment, but at addressing underlying issues that initially prompted the offender's actions, such as addictions and mental health problems. Offenders are guided and provided with the opportunity and facilities to receive treatment and training to overcome the issues that prompted them to offend. As Berman 


\section{International Journal of Social Science and Economic Research}

ISSN: $2455-8834$

Volume:05, Issue:08 "August 2020"

\&Feinblatt (2002); Frailing (2016) acknowledge, these courts are not perfect. However, they are beneficial, for they are aimed at guiding participants to lead more informed and useful lives. Not only do they demonstrate that judges teach, they also demonstrate that judges can transform and save lives when they teach.

Because the judgment, will explain how the law applies to the case, and why a party's case deserves to succeed and another's does not, it will include lessons about the law and justice. However, this is only possible if the judgment is good quality. Poor quality judgments are not good learning resources, and this was made clear by Lord Neuberger (2012) when he advised judges that:

Judgments must speak as clearly as possible to the public. This is not to suggest that Judgments could, or should, aim to be bestsellers. Chance would be a fine thing. But every Judgment could, or even should be sufficiently well-written to enable interested and reasonably intelligent non-lawyers to understand who the parties were, what the case was about, what the disputed issues were, what decision the judge reached, and why that decision was reached. Non-lawyers may not be able to grasp the finer details of the legal issues, because such understanding often can only come from many years of legal education and practice. They should however be able to understand what the case was about, even if they are unable to appreciate all the intricacies of the more abstruse legal principles.

It might be asked why this is important...

The particular reason is the right to a fair hearing... A clearly reasoned judgment enables the litigants to understand why the court arrived at its decision. As for the general reason, a clearly reasoned Judgment enables the public to understand the law and to see what is being done and said by the judges in the courts, to see how justice is being dispensed. Accordingly publicly pronounced Judgments represent an important means through which public confidence in and understanding of, the courts, and therefore the rule of law can be secured (pp.5-6).

In connecting the law to the facts and circumstances of a case, the judgment explains and applies legal ideas sociologically and practically, and so demonstrates the connection not only between the law and society, but also between the judge and society. It gives the judge the opportunity to keep the law alive and responsive to the needs and interests of society. It informs and assures members of society, that the law and the judge, are indeed part of them. If it is widely criticized by society, it can inspire a more informed judgment on appeal, or a 


\section{International Journal of Social Science and Economic Research}

ISSN: $2455-8834$

Volume:05, Issue:08 "August 2020"

change in the law by legislature. If it is widely accepted, it informs society that the law is functional, meaningful, beneficial, responsive, and relevant to it. Cardozo \& Kaufman (2010); Cotterrell (1998); Ehrlich (1903 \& 1975); Hart \& Hart (2012). Pound (1910); Přibóň (2017) among others, are of the view, that the law is connected to social welfare, and is made and applied to respond to interests and needs that exist in society.

\section{Constitutional rights}

Except for judges in countries such as China, who cannot enforce constitutional rights (Harding, 2017), judicial power allows judges to enforce constitutional rights, and so has the potential to provide important lessons in constitutional law and constitutional rights. Supreme Court judges in particular, can make land mark decisions that set valuable precedents for the protection of constitutional rights. Because the Supreme Court is the final court, its judges have the opportunity to evaluate the case from more angles, and so have the potential to give more informed decisions, and to serve as the best learning resource.

But even in cases where the Supreme Court has original jurisdiction, as the Supreme Court of The Gambia had in the recent case of YaKumbaJaiteh $v$ The Clerk of the National Assembly (2019), it can still give landmark decisions that address issues that have never been addressed, and provide valuable lessons about constitutional rights and principles. The case concerned section 88 of the 1997 Constitution of the Gambia, which empowers the executive to nominate members of the National Assembly, but does not expressly empower the executive to remove such members from office. In fact, there is no express provision in the said Constitution concerning the removal of such members. The Supreme Court of The Gambia, explained, for the first time, that the extent of executive power to appoint such nominated members of the National Assembly, does not go as far as to include the power to remove them from office, meaning that such members can serve for the same duration as elected members. The executive complied with the Supreme Court decision, and YaKumbaJaiteh was allowed to maintain her seat in National Assembly. The judiciary, executive, and legislature all confirmed their independence from each other, and demonstrated the constitutional principle of separation of powers for all to see. Although section 136 of a new draft constitution (2020), has responded to public demands to abolish the executive power to nominate members of the National Assembly, this was clearly a case where the judiciary, executive, and legislative branches of government loudly informed everyone, that the principle of separation of powers is a reality in The Gambia, and that constitutional rights will be protected. In essence, the case teaches the meaning of rule of law and constitutionality. 


\section{International Journal of Social Science and Economic Research}

ISSN: $2455-8834$

Volume:05, Issue:08 "August 2020"

On the international front, we also learn from the recent decision of the United Kingdom Supreme Court in $R$ (on the application of Miller) $v$ The Prime Minister \&Ors (2019), that the executive cannot exercise prerogative powers to suspend the activities of the legislature without reasonable justification. In that case, the executive also respected the principle of separation of powers and accepted the Supreme Court's decision, even though it expressed its reservations. Of course, not everyone will agree with Supreme Court decisions. Carrol (2020) for example, disagrees with the said decision by the Supreme Court of The Gambia, while Finnis (2019) and Nichols (2019) disagree with the United Kingdom Supreme Court decision. The point to make however-as confirmed by Landfried (2019), is that judicial decisions about constitutional matters, can raise political awareness, generate public debates, inspire ideas for improved governance and constitutional reform, and set high standards to shape a better and brighter future.

\section{Challenges}

Judicial power, like all powers, can be misused and abused. The fact that judges are required to be independent and impartial in their exercise of judicial power, is emphasized in abundant literature, including in Wilson's (1990) study about the impact of women judges. It is also emphasized in judges' codes of conduct, such as the Gambia's Judges Act 2009. However, judicial power can be misused to make political or partial decisions (Carman Jr., 2017; Stewart, 2003;). Consequently, it can model and inspire wrong behavior and injustice, and can inspire tensions and discord in society. It can be a blue print and catalyst for bad behavior, just as much as it can be a blue print and catalyst for good behavior.

Because of the emphasis on judicial independence, and the need to assure judicial independence, there is the concept of judicial immunity (Crowell, 2008), which means that judges cannot be sued for acts or omissions done in the exercise of their judicial power in good faith. Section 123 the same Gambian Constitution (1997) for example, provides that:

A judge or other person exercising power shall not be liable to any action or suit for any act or omission by him or her in good faith in the exercise of his or her judicial function.

Although this section of The Gambian constitution makes it clear that judicial immunity is not absolute, the words "in good faith in the exercise of his or her judicial function" as contained therein, may appear broad enough to give the impression that judges can get away with too much, and that rights of litigants are secondary to the rights of judges. Although Stengel (2012) emphasizes that alternative remedies such as the appellate procedure, prosecutions 


\section{International Journal of Social Science and Economic Research}

ISSN: $2455-8834$

Volume:05, Issue:08 "August 2020"

under the criminal law, and disciplinary procedure under judges' codes of conduct can alleviate the negative effects of a broad judicial immunity, he nonetheless recognized that broad judicial immunity can threaten rights of litigants.

Therefore, it must be emphasized, that the exercise of judicial power does not always yield positive learning experiences. It is certainly not my intention to assert that experience with judicial power will always be positive. In fact, a losing litigant and his supporters are likely to be disgruntled even if judicial power was properly exercised. Although it should be emphasized that there can be negative learning experiences with the exercise of judicial power, it must equally be emphasized, that such negative learning experiences are not always fatal, they can be mitigated and turned into positive learning experiences by the subsequent proper exercise of judicial power under the criminal law (by prosecution if the judge commits a crimes), on appeal to a higher court, or through disciplinary proceedings. For example, although the failure by a judge to observe the principle of precedent will be an improper use, or even abuse of judicial power, it can be addressed on appeal, or through disciplinary procedure.

\section{THE PRINCIPLE OF PRECEDENT}

\section{History}

Brenner (1990), traces the root of this principle as far back as fifth century England, and ties it to the English legal tradition of seeking consistency and following custom in resolving disputes. He explained that:

Between the fifth and twelfth centuries, English law was legitimated by tradition.

Exercises of legal authority were 'legitimate' to the extent that they were consistent with prior exercises of legal authority in similar situations. The system had developed an inventory of routine responses, or 'customs' that correspond to recurring factual situations. Adjudication proceeded by comparing a particular factual situation with the inventory of available responses and applying the response that most closely correspond with the facts presented.

'Precedent,' to the extent that it existed at all, was a purely empirical phenomenon, for example, reference to prior applications of custom in factual isomorphic situations. Although the system relied upon recitation of maxims as the mnemonic embodiment of custom, which recitation was not the invocation of abstract principles of legitimacy, but merely a symbolic linking of what was 'being done' with what 'had always been done.' 


\section{International Journal of Social Science and Economic Research}

ISSN: $2455-8834$

Volume:05, Issue:08 "August 2020"

There was no need for abstract principles of legitimacy because a particular exercise of legal authority was legitimate to the extent that it replicated an unbroken sequence of similar exercises (p. 517).

The understanding was that, issues which have been so often decided the same way, should continue to be decided the same way (Lord Coke in Spicer v Spicer (1620)). This is embodied in the Latin maxim stare decisiset non quietamovere-to abide by the precedents and not to disturb settled points (Black, 1886). However, in or about the nineteenth century, the use of custom to legitimize decisions was rejected, and decisions in previous cases rather than custom, were used to fill the void. Decisions in previous cases rather than custom, began to provide the basis for predicting a court's decision, and for making arguments on particular issues (Brenner, 1990), and hence the development of the modern concept of precedent, which prescribes that once a point had been settled by a decision of a competent court, it will not be subject to examination by the same court or other courts which are bound to follow its decisions (Black, 1886). Accordingly, the decision of the highest court will be final, and must be followed by the lower courts unless they can distinguish it (London Street Tramways Co Ltd $v$ London CC [1898] AC 375). Dworkin (1962), explains that an important reason for the existence of this principle, is that "in a Common Law country, [as opposed to a civil law country] where there is no comprehensive legal code, a consistent body of law must be developed. Inferior courts may haggle and differ, but the ultimate court must be majestic firm and consistent..." (p.168). Clearly, the rationale for having the principle was, still is, to ensure consistency, predictability, and order in the law.

Both Brenner (1990) and Lewis (1930), highlight the close connection between the history of precedent and the history of law reporting. According to them, precedent as we know it today, emerged as part of the English legal system only after the establishment of a more authoritative and reliable law reporting system in the nineteenth century. They underscore that precedent is heavily reliant on, and cannot be sustained in the absence of an accurate and reliable law reporting system. That being the case, the principle of precedent allows for credible legal resources, and is a credible learning tool. Certainly, lawyers, law academics, and law students rely on precedent to give credible legal opinion for justice to be served.

\section{Application}

The principle of precedent is a significant part of the Gambian legal system. In fact, it has constitutional recognition, and is enshrined in section 120 (1) of the 1997 Constitution, which as stated, places the Supreme Court at the apex, followed by the Court of Appeal, High Court, 


\section{International Journal of Social Science and Economic Research}

ISSN: $2455-8834$

Volume:05, Issue:08 "August 2020"

Magistrates' Courts, Cadi Court and District Tribunal, also by section 126 (1), which provides that the Supreme Court is the final court of appeal in The Gambia, and by section 26(2), which provides that all other courts shall be bound by the decision of the Supreme Court. And in keeping with the modern and flexible approach to precedent, the Supreme Court of The Gambia, like other final courts around the world, can depart from its previous decision when it appears to it right to do so (section 126(2) of the Constitution). The Gambian Constitution does not state whether or not the Court of Appeal is bound or not bound by its previous decisions. However, following the English case of Young v Bristol Aeroplane Co. [1898] A.C. 36, the Court of Appeal may depart from its previous decision in defined circumstances.

Therefore, the principle is not too rigid and oppressive, it allows judges of both the Supreme Court and Court of Appeal, the freedom and opportunity to correct their mistakes, learn from their mistakes, and grow intellectually and personally to produce even better judgments, which not only offer valuable lessons about the law and justice, but also serve justice. Vong (1985), hails the principle for its remarkable capacity to adjust to changing social conditions. And, the fact that the principle still allows the space for judges of the Supreme Court and Court of Appeal, to depart from their own previous decisions in appropriate circumstances, and to correct their errors and address the needs and interests of the community, confirms that it is dynamic and progressive. Its dynamism and progressiveness ensures it remains a credible learning tool and instrument of justice.

\section{Other Positive Aspects}

When judges abide by precedent, they demonstrate and model humility and restraint, which yields stability and order. Such humility and restraint can be emulated by lawyers, the public, and in many fora, to avoid chaos and anarchy. As a matter of fact, the concepts of humility, restraint, and discipline in the law are synonymous with the principle of precedent as observed by judges. Even Amaya (2017), who emphasizes that legal discussions must not restrict the concepts of humility and restraint to judges alone, admits that most of the time they are indeed restricted to judges. Therefore, the principle of precedent allows judges to be the main teachers of restraint and humility in the law.

Significantly, because the Supreme Court and the Court of Appeal can depart from their previous decisions (albeit in defined circumstances), and because a lower court can distinguish the facts of a case decided by the higher courts, and further because there is sometimes no precedent on an issue, the principle of precedent does not necessarily make it possible to predict the outcome of every case. This means that we can learn something new from almost 


\section{International Journal of Social Science and Economic Research}

ISSN: $2455-8834$

Volume:05, Issue:08 "August 2020"

every case, and so the principle of precedent does not necessarily yield a predictable, mechanical, and uninspiring legal system. In essence, it does not prevent a new issue from being addressed and determined to serve justice.

Notably, it is only the reason for the decision (the ratio decidendi) of the higher court that binds the lower courts, and this is ably demonstrated in Salmond's (1957) definition of precedent as:

...a judicial decision which contains in itself a principle. The underlying principle which thus forms its authoritative element is often termed the ratio decidendi. The concrete decision is binding between the parties to it, but it is the abstract ratio decidendi [reason for the decision] which alone has the force of law as regards the world at large (p. 102).

Therefore, it is not every aspect of the decision of a higher court that binds a lower court, which means that the lower courts have significant freedom. Lower courts are not muzzled, and in the name of justice, can criticize (albeit with courtesy), the unfairness and injustice of a precedent they are bound to follow. They can accordingly maintain their intellectual integrity, and can make intellectual contributions that inform a reconsideration and overruling of a precedent by the very court that set it to do justice. For example, Lord Denning's disagreement and reasoning in the case of Chandler $v$ Crane Christmas and Co (1951), where the majority decision relied on precedent set by the House of Lords in Derry v Peek (1889), to hold that damages for negligent misstatement was not payable to a third party who had no contractual relationship with the maker of the statement, subsequently found favor with the House of Lords in the case of Hedley Byrne and Co Ltd v Heller and Partners Ltd(1964), where it was decided that damages could be recovered for negligent misstatements where a duty of care existed between the maker of the statement and the other party who relied on the statement, irrespective there was no contractual relationship between them.

Inspired by Goldstein (1987) and Anderson (1995), Akinmidu (2001) highlights how the principle of precedent motivates critical thinking, objectivity, and inspiration for reflection and testing of previous decisions for their fairness, soundness, and relevance with the passing of time to achieve justice. He said:

The uniqueness of the doctrine of precedent should not, in our view, bargain with an assumed presupposition that some particular judgments, perhaps by their soundness and precision, should become authoritative patterns for future decisions. Rather, precedent in law should result from the testing of cases in search for justice. This is why Peczenik's definition of Precedents as "a decision of concrete case which becomes an authoritative 


\section{International Journal of Social Science and Economic Research}

ISSN: $2455-8834$

Volume:05, Issue:08 "August 2020"

pattern of future decisions "(Peczenik 1989), is an assertion that favors presupposition conditionality which blocks the route for adequate testing of cases in order to determine the relevance of the application of precedent in the adjudication of cases in law. The testing process is only useful if the mechanism of searching for justice towers higher than established presuppositions. Apparently, any judgment can become a precedent if it coheres with fairness and this coherence establishes relevance with adjudged past case(s).

Therefore, precedent as a doctrine is retrospective as a general rule but not gazing into the future under the aegis of presuppositions (p. 246).

And although Akanmidu (2001) was focused on the value of precedent to judges specifically, it is clear that the principle of precedent can inspire everyone to question judicial decisions, and can trigger positive changes in the law and in policy. This will be in line with Ehrlich's (1975) view, that the law is, and should be a living instrument reflective of and responsive to social needs, for a better ordered society, and Loughran's (1953) observation that:

...if we were to be limited to slavish adherence to precedents and were not free to apply the decisions and their underlying principles to changing conditions and situations which did not exist and were not contemplated when the decisions were made, our decisional law would in great measure be no more advanced today than it was many generations ago. The common law has been able to maintain its preeminent place over the centuries because of its stability and its inherent capacity for keeping pace with the demands of an ever-changing and evergrowing civilization (p.1).

Apart from the fact that the principle of precedent allows the legal fraternity and the public to be aware of the judicial stance and the position of the law in relation to a particular subject matter, and offers some guidance for the present and future, it also facilitates the decision making role of lower courts. It ensures that lower courts are never short of resources to guide them reach decisions. It ensures that lower courts are equipped to deliver informed judgments.

Which means that the potential for error and injustice by lower courts is minimized. It also means that lawyers too are never short of resources to guide them give opinions and make submissions, even if (Robbins, 2002; Whisner 2004) highlight that some lawyers do not make good use of the resources available to them, and do not cite their sources accurately and meaningfully, to the annoyance of judges.

\section{Challenges}




\section{International Journal of Social Science and Economic Research}

ISSN: $2455-8834$

Volume:05, Issue:08 "August 2020"

Weinstein (2004) proposes that judges must lay down their professional lives for justice. He argues that judges embrace their professional lives most fully, when they are prepared to fight, and be criticized or reversed in striving for justice. It appears that, for him, justice- not precedent, must be the priority. Also, as observed by Vong, 1985, not all cases are applied for rectification by higher courts. If a bad precedent is not appealed to a higher court, it remains law. The principle of precedent therefore, does not always yield the opportunity to rectify errors and be progressive, and does not always yield credible learning resources. In essence it does not ensure that justice will always be served.

Palmer, (2009) explains, that judges can usually avoid precedent they are obliged to follow and expected to follow, by simply reframing their cases to agree more with a different and unrelated precedent that supports their thinking. This certainly makes the idea of precedent seem redundant. It must also be emphasized, that there is a lot of opposition to the idea of judicial activism. Bennett, (2009); Devlin (1976); Devlin (1979); Powell Jr. (1990); Siegel (2009), all emphasize and prioritize judicial restraint and discipline over Judicial activism. They underscore that although change is inevitable, consistency, discipline, stability, restraint and moderation are also crucial to maintaining public confidence in the law. They argue that if there are no serious restrictions against undisciplined and self-indulgent avoidance of precedent, then no precedent will be permanent to be able to guide and inform future actions.

The ratio decidendi of a decision may be unclear, or narrowly interpreted. And as was observed by Lord Denning in Close v Steel Co. of Wales (1962), there is no set method for determining the ratio decidendi of a case, meaning there is a broad license for determining what the ratio decidendi of a case is. And so, the ratio decidendi of a case can be easily misconstrued or not determined at all, and can be deliberately ignored, which again, would make the principle of precedent appear futile. Another major issue, as pointed out by Cohen (2015), is that the reasons actually forwarded by the judge as the reasons for his decision, may not be the actual reasons for his decision, or may be reasons that have nothing whatsoever to do with the justice of the case. This demonstrates that the principle of precedent can be manipulated to cause injustice, and is not always a good model for discipline, restraint, and humility. As already stated, when judges exercise their discretion, they are not bound by precedent (Devlin, 1976; Hart \& Hart, 2012; Kyriakides, 2016). They decide cases on their own particular facts and merits, rather than on the facts and merits of a supposed precedent. That being the case, the principle of precedent does not always apply to inform and guide future actions. It can be an inconsistent and unreliable teacher. 


\section{International Journal of Social Science and Economic Research}

ISSN: $2455-8834$

Volume:05, Issue:08 "August 2020"

There is not much deterrence against the undisciplined avoidance of precedence. Failure to follow precedent is hardly considered a judicial misconduct that attracts disciplinary procedure. This was made clear by Palmer (2009), who pointed out, that though there are judges who refuse to follow precedent and act outside the confines of the law, such judges are merely criticized and reversed on appeal, and are hardly disciplined because of the high value placed on judicial independence. Nevertheless, judges who follow precedent or refuse to follow precedent within the confines of the law, are good role models, which makes them valuable teachers and valuable instruments of justice.

\section{JUDGES AS ROLE MODELS}

\section{Definitions of role model}

Morgenroth et al (2015) define roles models as "individuals who influence role aspirants' achievements, motivation, and goals by acting as behavioral models, representations of the possible, and/or inspirations" (p. 4). On the teachers' website Teach.Com (n.d), a role model is defined as:

A person who inspires and encourages us to strive for greatness, live our fullest potential and see the best in ourselves... someone we admire and someone we aspire to be like. We learn through them, through their commitment to excellence and through their ability to make us realize our own personal growth. We look to them for advice and guidance (n.p.).

Dechalert (2019) realistically opines, that the point of a role model, is not to aspire others to be like them, but "to guide your personal actions and decisions towards the ability to create your own journeys based on your own personal circumstances (n.p.).

What the above definitions have in common, is the perception that role models are, or should be positive influencers of thinking and action. From Bostock's (2014) study about female role models, we learn that people who hold high conspicuous positions (such as judges), will be role models, because others will inevitably observe their behavior and pick up clues from them. Krauss Whitbourne (2013) citing the study by Brown \&Treviño (2013), also explains that people tend to copy the behavior of those who get attention for what they do, and so supports the suggestion that prominent people (which includes judges) will inevitably be role models. Both Aspen (1994) and Joy (2000), suggest that judges are role models especially because they are expected to lead by example. Their contention is, that judges must lead by example. They believe that judges cannot expect standards of behavior which they themselves do not live up to in the first place. 


\section{International Journal of Social Science and Economic Research}

ISSN: $2455-8834$

Volume:05, Issue:08 "August 2020"

In fact, Baum (2009), in his discussion about American judges and their audiences, suggests that judges are very much aware of their role model status, and would often strive to maintain this status to meet public expectations of them. Although Baum (2009) underscores that judges' personal needs to win their audience, and to maintain public esteem, confidence, and recognition would normally motivate them to behave properly and maintain their role model status, it is clear that judges can also be motivated, and can in fact be obliged to behave properly and maintain their role model status by impersonal factors, such as their codes of conduct. When judges behave properly and maintain their role model status, they inspire the same behavior in the public, they inspire the public to expect high standards of behavior, and they inspire public trust and confidence.

\section{Codes of conduct}

Judges' codes of conduct require judges to act professionally and ethically. They aim to make judges positive role models. Krauss Whitbourne (2013) argues, that one way of getting people to learn ethical behavior and to become ethical leaders, is by having ethical role models. She therefore reminds us that role models do not always influence positively-that there are bad role models. In the Gambia, sections 2 to 19 of the Judges Act (2009), sets the standards for proper judicial behavior. Judges are obliged to respect the Constitution, to be independent, to act with integrity and fairness, to be impartial, to avoid impropriety in their decision making, to treat everyone with respect and courtesy, not to engage in partisan politics or unnecessarily fraternize with politicians, to recuse themselves where there is conflict of interest, to be diligent in the performance of their duties, to be decisive and prompt in the disposition of judicial business, to be punctual for duty, to give judgments and decisions with reasons as soon as reasonably possible, and to ensure equality to all persons.

Judges should model all the qualities required of them by their codes of conduct to nurture those same qualities in the community they serve. However, judges who do not share the same values with their communities cannot be good role models for their communities. Hence, Ifill (2000) while discussing issues of diversity in the appointment of American judges, argues that the primary consideration should be to appoint judges who are willing to serve and represent the values of their community, and not to appoint judges simply because they are members of the community. His point is that, a judge who is a member of a community, but does not share and represent the values of the community, will not be useful to the community.

Judges are not held to high standards of behavior because they are expected to be perfect. Pacht (1984), and the scientist Stephen Hawking (as reported by Vultaggio, 2018), inform us 


\section{International Journal of Social Science and Economic Research}

ISSN: $2455-8834$

Volume:05, Issue:08 "August 2020"

that perfection is a non-existent and unattainable concept. Certainly, Justice Robert Jackson in Brown v Allen (1953), made it quite clear, that judges, like all other human beings, are not infallible. Judges are held to high standards because of the great power and responsibility that comes with their office. This fact was ably explained by the Massachusetts Supreme Court in Re Morrissey (1974)as follows:

That the standards imposed on judges are high goes without saying. Because of the great power and responsibility judges have in passing judgment on their fellow citizens, such standards are desirable and necessary and there should be strict adherence to them. Failure on the part of even a few judges to comply with these standards serves to degrade and demean the entire judiciary and to erode public confidence in the judicial process.... (pp. 1617).

Judges are held to high standards because of the trust people have in them, the expectation people have that they are credible and capable of judging them, and because of the great power they are given to interfere in the lives of others, and to judge others, who must obey their decisions even if it means loss of life or livelihood. They have a great responsibility, which demands nothing but greatness, and which should have room for nothing but integrity. It is important that they are trusted and respected, because if they are not trusted and respected, people will no longer rely on the courts for justice, they will resort to taking the law into their hands. Weisenberg (2018) in his commentary for the American Bar Association Journal highlighted the vast powers and responsibilities of judges, which vast powers and responsibilities would justify the high standards of behavior expected from them. He said:

Judges and courts have a significant impact on our daily lives and we entrust them to make some of the more important decisions that affect us... Only a judge can grant a divorce, confirm an adoption, order the termination of parental rights, sentence a person to death, impose a sentence of imprisonment or cause a change in property rights.

Judges and courts exist to protect our liberties and our most fundamental and sacred rights, ...as well as to protect us from unlawful and unwarranted intrusion into our lives from the government.

Without our courts there is no justice, there is no freedom...

Today, more than ever, our courts serve as a safe haven for the peaceful resolution of disputes. Conflict and disputes are part of life and whether it is a contract that is alleged to have been breached, a marital relationship that is broken, a dispute over the provisions in a will, a dispute between a landlord and tenant, an alleged case of medical or legal malpractice, or any other dispute that arises, it is our courts that are called upon to hear the dispute... (paras. 3- 6). 


\section{International Journal of Social Science and Economic Research}

ISSN: $2455-8834$

Volume:05, Issue:08 "August 2020"

Martineau (1981) also observed that:

The ultimate reason for any type of judicial discipline is to maintain public confidence in the judiciary. The logic behind this principle is simple: a legal system can function only as long as the public accepts and abides by decisions rendered by the courts; the public will accept and abide by these decisions only if it is convinced that the judges are fair and impartial; anything that tends to weaken that conviction should be avoided. In other words, justice must not be done, but must also appear to be done. For this reason, judges are commanded to avoid not only actual impropriety but also the appearance of impropriety in all of their activities (p. 227).

Codes of conduct aside, it is inevitable that a judge's words and actions, in court or out of court, will resonate with some, to provide them with inspiration, motivation, support, or validation. Lawyers and litigants come into contact with different types of judges, and most often, there will be a judge who speaks for them, enlightens them, or resonates with them in such a way as to reinforce their confidence in the justice system, or to nurture their selfconfidence and self-worth, so that they live up to their fullest potentials and be more fulfilled. This is confirmed by the many praises heaped on judges-especially in the United States, among these Dechalert (2019), who identifies Judge Judy as her role model, and says Judge Judy's individualistic philosophy and approach to work and life, inspired her to figure out who she is. Noble (1993), who praises judge Higginbotham for setting a remarkable example by always being "fair, decent, and caring" (p. 551), Judge (2019), who praises Judge Posner for allowing his humanity and the humanity of others to shape his judgment; and Bodnar (2019), who, while highlighting the missteps of a particular judge, emphasizes how he was inspired by another one:

During my career, I had the privilege of interacting with retired federal Judge Lawrence Stengel multiple times in court and at various outside events. An accurate description of him is that he is a 'down to earth' person. Stengel has an air of dignity, yet is personable and connects with people. I've always found him to be approachable, respectful, helpful and willing to listen. Best of all, he is a nice man who maintains perspective. He is just one example of a community leader whose traits should be emulated...(n.p.).

\section{Challenges}

The reality (as admitted by Aspen, 1994 and Joy, 2000), is that judges do not always live up to expected standards of behavior. Therefore, they are not always positive role models. When they are not positive role models, they cannot be credible teachers. However, when that happens, they can be disciplined in line with their codes of conduct to assure the public. 


\section{International Journal of Social Science and Economic Research}

ISSN: $2455-8834$

Volume:05, Issue:08 "August 2020"

Significantly, they will be treated like any other person if they commit wrongs outside the course of their duties or committed in the course of their duties with faith-especially if those wrongs are crimes. Hence, in the Indian case of Arundhati Ashok Walavalkar $v$ State of Maharashtra \&Anor (2004), where a Magistrate was charged, prosecuted, and convicted for traveling three times on a train without a ticket, the Supreme Court of India underscored that:

In a country governed by rule of law, nobody is above law including judicial officers. In fact, as judicial officers, they have to present a continuous aspect of dignity in every conduct. If the rule of law is to function effectively and efficiently under the aegis of our democratic setup...(para. 29).

In the United States, a number of judges have been subjected to the law (especially the criminal law), like everyone else. There was the "Kids for cash" scandal, which saw two judges (Michael Conahan, Mark Ciavarella) prosecuted, convicted and sentenced for receiving bribes to sentence juveniles to a profit making detention center (Guggenheim \& Hertz, 2016). Among the most recent cases, is one reported by Barry (2019) in The New York Times, about Judge Shelly Joseph, who was charged with obstruction of justice and helping an undocumented immigrant escape detention. Another is a report by Shanahan (2019), also in The New York Times, about a federal judge, Justice Sylvia Ash, who faced obstruction of justice charges related to corruption at a Municipal Credit Union. When judges are treated equally under the law, the public are sensitized and assured, that no one is above the law. It develops confidence in the justice system. Importantly, it informs and reminds others in positions of power to act within the law.

A major issue with treating judges as role models, is that it might raise expectations for them to be perfect. Although it is accepted that perfection is unattainable, Bostock (2015) informs us that being a role model suggests an expectation of perfection, and so can be a burden. The expectation of perfection might weigh too heavily on judges' mind to affect their performance.

In fact, Hoffman (2017) explains that striving for perfection can have a negative impact on mental health. Therefore, it should not be suggested or expected that judges model or teach perfection. The challenge however, will be for judges to use their role model status realistically without expectation of perfection, and for the public to have realistic expectations of judges, which understands that perfection is unattainable.

\section{ALTERNATIVE ARGUMENTS}

The idea of judges as teachers in any legal system, is undermined by discussions by D'Amato (1977); Nakad-Westrate et al (2015) about the possibility of human judges being replaced by 


\section{International Journal of Social Science and Economic Research}

ISSN: $2455-8834$

Volume:05, Issue:08 "August 2020"

computers, and highlighting the benefits of judgements delivered by computers free of human intervention. D'Amato (1977) argues that backlogs of cases, biases, and rights infringements which occur before human judges, can be overcome if computers replace human judges, and van den Herik (1991) as cited by Nakad-Westrate et al (2015), predicts that courts of computers will eventually replace courts of reason.

The fact that many judges identify themselves simply as law appliers, (Flango et al,1975), indicates that many judges are not concerned with teaching, and believe their task is not to teach. And because judges are not supposed to make laws or initiate changes in the law, their teaching role is dependent on the legislature and the public, and so is restricted. Pound (1906) and Wilson (1990), remind us that changes in the law comes slowly and incrementally, which means that opportunities to learn something new from judicial decisions can be few and far between. Although Resnick (1988) argues that the qualities of impartiality, independence and disengagement can exist side by side with virtues such as nurturance, interconnectedness and interdependence, which all underlie the teaching role of judges. Emphasizing the teaching role of judges might actually distract some judges from their very important duty to be independent and impartial, and to make justice a priority. It might distract some judges away from the real issues between the parties, and into showing off their teaching skills and grandstanding. It can threaten judges' perceived independence and impartiality. Judges might no longer be seen as independent of teachers or groups affiliated with the teaching profession, and they might in fact be inclined to be sympathetic towards teachers and similar groups.

An emphasis on the teaching role of judges, might cause some judges to be more formalistic and rigid, for they might want to show that they are following the rules, and are good teachers. Posner (2013), however highlights that too much formalism restricts substantial justice. Some judges might be tempted to use their superior position as teachers, as license to give lawyers, litigants, and the public, even more patronizing lectures than they would normally give. In other words, although judges must be humble (Davis, 2019; Williams, 2013; Amaya, 2018; Nava, 2007), their teaching role can inspire haughtiness and pomposity, which might hinder any interest to learn from them.

When judges focus too much on their teaching role, they might feel they have to express themselves in more detail to be clear and impactful, and their judgments are more likely to contain academic and irrelevant discussions just to show off their intellectual prowess. And when judges try to explain themselves in more detail, they are more likely to ramble off and say something offensive, or express themselves wrongly to attract scorn and public criticism. 


\section{International Journal of Social Science and Economic Research}

ISSN: $2455-8834$

Volume:05, Issue:08 "August 2020"

Under the circumstances, their teaching role can make them more vulnerable to scorn and public criticism. It can also make them more vulnerable to attacks questioning their intellect.

The need to show off their intellectual prowess and knowledge, might push judges to write complicated judgements, Lord Neuberger (2012) however advises against the anxious parade of knowledge and elaborate judgments. He argues that because the readership of judgments consists not only of lawyers and judges, but also litigants and future litigants not legally trained, judgements should be simple and clear. As he puts it:

It is not realistic to expect that every Judgment could be understood by everyone: human nature, the complexities of modern life, and the intricacies of the law do not permit that. However, if we are to maintain public confidence in the justice system, judges must make their judgments as accessible as possible, particularly to members of the public and litigants-in person... By rendering our judgments as clear, as accessible, and as comprehensible, as possible we place that which is of value in them in sharper focus: rather than diminishing our Judgments, it would enhance them (p. 14).

Although there are studies such as those by Koppensteiner (2020) underscoring that the vulnerability of the teacher is crucial for bonding the teacher to the student, and for helping the teacher achieve transformative solutions that benefit both teacher and student, some judges might not feel comfortable putting themselves in any vulnerable position to connect with litigants, and they might feel their duty to be independent and impartial prevents them from bonding and connecting with litigants.

If the teaching role of judges is given much prominence, some judges might feel they are being given additional responsibilities, and might feel overburdened. Even if they were already doing a good job, they might feel they will have to work harder, which might increase their stress levels. They might also take more time to write their judgments, which will cause backlog of cases, disgruntled litigants, and loss of confidence in the justice system. Indeed, there will be judges who are oblivious to their teaching role, and so will not be able to discharge it effectively to educate the public.

Pound (1906), in discussing the reasons for the dissatisfaction with the administration of justice in the United States, observed that court procedure is contentious and requires parties to fight their "own game in their own way without judicial interference" (pg. 7). Litigation he contends, is simply a game to be won by those who can beat or evade the law, and not necessarily an independent search for truth and justice spearheaded by judges with clout. The deduction from by Pound (1906) is that, some judges will have limited or no opportunity to teach anything of value, because they are more like spectators. 


\section{International Journal of Social Science and Economic Research}

ISSN: $2455-8834$

Volume:05, Issue:08 "August 2020"

A significant point to make, is that while some judges recognize their teaching role, love to teach, and are motivated to excel by their teaching role, other judges are simply not cut out for a teaching role, and are not disposed to teach. In his book about "bad Judges" Williams (2013) demonstrates that some judges lack the temperament to adequately discharge their functions (and indeed their teaching role). They are described as rude, inattentive, uncaring, out of touch, impatient, self- absorbed and unprincipled. Such judges cannot be good teachers. Davis (2019) and Richardson (2016) discuss judges who suffer from 'black robe disease' or 'black robe fever'. These judges are described as bullies, self-absorbed, self-aggrandizing, dogmatic, impatient, lacking empathy, hostile, prone to unnecessary outrage and anger, unable to manage their cases effectively, and generally not efficient. Such judges are the opposite of what good teachers should be. Campbell (1856) also made it clear, that some judges can be tools of tyrants and instruments of oppression, rather than be teachers.

Clearly, such judges cannot, and will not make sound decisions to be good teachers, and this was ably demonstrated in a Reader's Digest article by Burnett (n.d.), who exposed a number of judicial conduct antithetical to teaching, including: a judge who took five months to hear the case of a maltreated child, and after hearing the case failed to give a decision while the child languished in foster care with an uncertain future; a judge who sentenced an unremorseful person convicted on four counts of manslaughter to probation; a judge who sentenced a repeat rapist to home detention instead of prison; a judge who did not wish to recognize the Sikh religion; and a judge who relied on the sexual history of a victim of rape, to sentence the rapist to mere community service. These judges according to Burnett (n.d.), neglect victims and enable offenders, and so cannot be of much use to the community.

The 'black robe disease', or black robe fever', Or robe -itis (as it is also referred to in the exposé by Davis, 2019), makes judging contrary to teaching. Of course, not all judges have this disease. Many judges are principled, attentive, compassionate and understanding, which qualities Eldergill (2015) emphasize should not be absent from judging. These judges are the complete opposite of the judges Davies (2019); Richardson (2016); and Williams (2013) condemn, and should therefore be capable of discharging their teaching role effectively. Yet, because of the high value placed on judicial independence, such judges can nonetheless appear cold, detached and inattentive, or at least feel they have to appear that way. This further demonstrates, that the obligation to be independent (or at least appear independent), can hinder the proper performance and appreciation of the judge's teaching role- even if studies by Bandes (2017); Eldergill (2015); and Resnick (1988) inform us, that the principle of judicial 


\section{International Journal of Social Science and Economic Research}

ISSN: $2455-8834$

Volume:05, Issue:08 "August 2020"

independence need not be threatened by, and can exist side by side with humanistic qualities of judges.

\section{CONCLUSION AND WAY FORWARD}

I have argued and demonstrated, that judges have an invaluable teaching role, that their teaching role allows them to do justice and justify their positions, and also to confirm their utility and relevance. I have also demonstrated that their teaching role can yield public trust and satisfaction with the administration of justice. I also highlighted the challenges that hinder the effective performance of their teaching role. These challenges are faced by judiciaries across the world, they interfere with the course of justice, and hence the reports that there is lack of trust in the administration of justice globally. Gloppen (2013), for example, finds there is lack of trust and confidence in the administration of justice globally. The global lack of trust in the administration of justice, would indicate that the judge's teaching role is being underperformed globally despite its importance.

As Lord Hewart advised in $R v$ Sussex Justices, Exparte McCarthy [1924], "Nothing is to be done which creates even a suspicion that there has been an improper interference with the course of justice" (p. 259). If judges perform their teaching role effectively, then the general lack of trust, and dissatisfaction with the administration of justice will be minimized. The aim, must therefore be, to ensure judges excel at their teaching role. A first step, must be, to broaden judicial training content to include this role- for judges to be sensitized about it, so that they are more mindful of it and perform it better. This will certainly be a progressive step. Conners (2015) suggests that judicial training and trainers, must be forward looking, progressive, and transformative to be able to impress these same qualities on the judges being trained. Her suggestion is a reminder that the quality of judicial trainers is key to making judges effective teachers, and that judicial trainers have to be progressive and transformative if they are expected to include the teaching role of judges in training content, and if they are expected to properly train judges perform their teaching role.

If judicial trainers are to inspire and impress upon judges to value and properly discharge their teaching role, they (the trainers), must in the first place be progressive and forward looking enough to value the teaching role of judges. However, judicial trainers cannot be progressive if they are restricted by persistent archaic justice systems, which systems Pound (1906) argued, can be a reason for dissatisfaction with the administration of justice. Sadly, Conners (2015) informs us, that judicial trainers (and indeed justice systems), are yet to be sufficiently progressive. 


\section{International Journal of Social Science and Economic Research}

ISSN: $2455-8834$

Volume:05, Issue:08 "August 2020"

Judges can transform and save lives when they properly perform their teaching role. But some judges might not be aware of this fact. The argument by Conners (2015), is that judges will perform much better if they are more aware of their value, and their ability to transform lives for the better. Therefore, the more judges are made aware of their teaching role and how it enables them transform and save lives, and the more they are trained to perform their teaching role effectively, the more likely they will remain motivated and committed to excel at it. If they excel at their teaching role, they strengthen faith in the administration of justice.

Ehrlich's (1903) contention, was that there is no greater guarantee of justice than the personality of the judge. A judge who does not have the personality of a teacher, cannot be expected to be an effective teacher. Therefore, it is also crucial that judicial training focuses on nurturing the right qualities and personality that allows judges to discharge their teaching role effectively. Judicial training should also place more focus on nurturing valuable teacher qualities- for example, qualities such as humility, compassion, patience, and understandingwhich qualities Bandes (2017); Eldergill (2015); and Resnick (1988) will argue, are, or should be inextricably linked to the idea of justice in any event, and so can exist side by side with the judge's duty to be principled, independent, and impartial. On this account, current methods of selection for judicial office can also be broadened, to include considerations of characteristics or personality that would facilitate the effective performance of judges' teaching role.

Although broadening the content of judicial training will be a good step, it will not be enough to ensure that judges perform their teaching role effectively, and are sufficiently appreciated. More needs to be done. Judges need adequate resources if they are to discharge their teaching role effectively. However, the International Commission of Jurists (2007) found that lack of adequate judicial resources is a major issue generally, but especially in developing countries and can be the cause of corruption. They also found that lack of resources yields inefficiency and demotivation, because without the resources, members of the judiciary cannot perform their functions, and cannot be motivated to work. Lack of adequate resources however, remains a challenge for developing countries (Puymbroek, 2001).

World Justice Project (2019), provides insights about the lack of judicial independence and general poor perception of justice that persists around the world. I believe these factors can also hinder the recognition and appreciation of judges as valuable teachers. If judges are not independent and highly perceived, no one will listen to them to learn from them. Judges must live up to expectations if they are to be appreciated for their teaching role. Furthermore, as earlier noted, when a country faces high poverty and illiteracy rates, as most developing 


\section{International Journal of Social Science and Economic Research}

ISSN: $2455-8834$

Volume:05, Issue:08 "August 2020"

countries do, it will be difficult to secure high level public interest in court proceedings and justice. Yet judges cannot be understood and appreciated if there is no public interest in court proceedings and justice. Therefore, the public-especially the more vulnerable members of the public, must be encouraged to develop interest in court proceedings and justice. Also, as earlier noted, there is hardly any literature exploring the teaching role of judges, and hardly any prominence given to the teaching role of judges. This indicates a lack of interest in the topic, which also means there is no significant demand for it to be made part of judicial training content. Judicial training content will not be broadened to include the teaching role of judges if there is no significant demand for it to be so broadened. Under the circumstances, efforts to promote interest in the topic must be intensified.

While this discussion stems from a sincere appreciation of the teaching role of judges, and is intended to promote, and make prominent the teaching role of judges, it also amply appreciates the many obstacles facing this role. Unless these obstacles are addressed, this role though vital for nurturing and ensuring public confidence in the administration of justice, will remain largely obscure, muted, underperformed, and unappreciated. The obstacles are not insurmountable, what is perhaps required is an intensification of the efforts to surmount them, or a change in the approach to surmount them.

\section{References}

A World Bank/International Records Management Trust Partnership Project (2001). Evidence-based governance in the electronic age: case study: legal and judicial records and information systems in The Gambia.https://www.yumpu.com/en/document/read/18811934/thegambia-international

Akanmidu, R.A. (2001). The morality of precedent in law.Ratio Juris, 14(2) 244-51 Ala. L. Re., 59, 453

Allot, A.N. (1968). Judicial precedent in Africa revisited. Journal of African Law, 12(1), 3-33. Doi: https://doi.org/10.1017/S 0021855300006124

Amaya, A. (2018). The virtue of judicial humility. Jurisprudence, 9(1),97-107

Armytage, L. (1993). The need for continuing judicial education. UNSW Law Journal 536

Armytage, L. (2015). Leadership for judicial educators: vision for reform. In Journal of the International Organization for Judicial Training Armytage, L., Carmi, A., Campbell, C. McDowell, A., (Eds.) (2015), Issue 3, pp.16-34. National Center for State Courts.

Aspen, M.E. (1994). The search for renewed civility in litigation. Val. UL Rev., 28, 513

Bandes, S. A. (2017). Compassion and the rule of law.Int'l JL Context 13, 184 


\section{International Journal of Social Science and Economic Research}

ISSN: $2455-8834$

Volume:05, Issue:08 "August 2020"

Barak, A. (2002). A judge on judging: the role of the Supreme Court in a democracy. Harv. $L$. Rev.116(16), 19-162

Barnett, R. E. (2004). The original meaning of the Judicial Power.Supreme Court Economic Review 12, 115-138. https://scholarship.law.georgetown.edu/facpub/839/https://ssrn.com/abstract=437040

Barry, E. (2019). When the judge becomes defendant.The New York Times.https://wwwnytimescomcdn.ampproject.org/v/s/www.nytimes.com/2019/11/16/us/shelleyjosephimmigration-judge.amp.h...

Bartlett, B. (2010). Ethical breach and the schizophrenic process: theorizing the judge and the teacher. Journal of education controversy, 5(2), 8.

Barton, B.H. (2007). Do judges systematically favor the interests of the legal profession? University of Tennessee Legal Studies $\quad$ Research $\quad$ Paper $\quad$ No. 1 https://papers.ssrn.com/sol3/papers.cfm?absract_id=976478

Basten, J. (2005). Court and media relationships.National Judicial College, Beijing Conference -30 October to $4^{\text {th }}$ November 2005

Baum, L. (1994). What judges want: judges' goals and judicial behavior.Political Research Quarterly, 47 (3), 749-768

Baum, L. (2009). Judges and their audiences: a perspective on judicial behavior. Princeton University Press.

Berger, B. L. (2018). What humility isn't: responsibility and the judicial role.In Jutras, D. \& Moore, M. (Eds).The Chief: essays in honour of Chief Justice Beverley McLachlan(forthcoming) https://papers.ssrn.com/so/3/papers.cfm/abstract id $=3269547$

Berman, G., \&Feinblatt, J. (2001).Judges and Problem-Solving Courts.Center for Court Innovation.

Black, H.C. (1886). The principle of stare decisis.745-756 The American Law Register

Black, H.C. (1968). Black's law dictionary definitions of terms and phrases of American and English jurisprudence, ancient and modern. $4^{\text {th }}$ Ed. Rev. West Publishing Co. St. Paul, MI https://www.1215.org

Bodnar, B. (2019). Judges should strive to be role models. Lancaster Onlinehttps://lancasteronline.com/opinion/letters_to_editor/judges-should-...

Borrows, L. (2016).Dabaadendiziwin: practices of humility in a multi-juridical legal landscape. 33 Windsor Y.B. Access Just.149

Bostock, J. (2014). The meaning of success. Cambridge University Press

Botero, J.C., La Porta, R., Lopez-de-Silanes, F.,Volokh, A. (2003). Judicial reform.The World Bank Research Observer, 18 (1),61-88 


\section{International Journal of Social Science and Economic Research}

ISSN: $2455-8834$

Volume:05, Issue:08 "August 2020"

Brantmeier, E.J., \& McKenna, M.K.(Eds.). (2020).The pedagogy of vulnerability. IAP.https://books.google.gm/books?id=_qPbDwAAQBAJ\&pg=PR7\&source=gbs_se...

Brennan, G. (1996). Why be a judge? Presented at New Zealand and High Court and Court of Appeal Judges' Conference, Dunedin April 1996.

https://www.hcourt.gov.au/assets/publications/speeches/former-ju...

Brenner, S.W. (1990). Of publication and precedent: an inquiry into the ethnomethodology of case reporting in the American legal systems. De Paul L. Rev., 39(3), 461

Brown, M.E., \&Treviño, L.K. (2013). Do role models matter? An investigation of role modelling as an antecedent of perceived ethical leadership.Journal of Business Ethics, 122(4), 587-598.

Burnett, D. (n.d.). 5 judges who will erode your faith in the system.Reader's Digesthttps://www.rd.com/culture/bad-judges/

Capurso, T.J. (1998). How judges judge: theories on judicial decision making. University of Baltimore Law Forum, 29(1) 2, 5

Cardozo B.N., \& Kaufman, LA. (2010). The nature of the judicial process. Quid Pro Books

Carman, R. (2017). Making good law or good policy?: the causes and effects of State Supreme Court Judges' Role Orientations. Springer

Carrol, H.D.R. (2020). Legal postmortem of the first Supreme Court judgment in YaKumbaJaiteh's case.The Standard.https://standard.gm/legal-postmortem-of-the-firstsupreme-court-judgment-in-ya-k...

Clark, C.E., \&Trubeck, D.M. (1961). The creative role of the judge: restraint and freedom in the common law tradition. The Yale Law Journal, 71, 255

Cohen, M. (2015). When judges have reasons not to give reasons: a comparative approach. Washington and Lee Law Review, 72(2), 483

Collier, C. (1988). Precedent and legal authority: a critical history. Wis. L. Rev, 771 https://scholarship.law.ufl.edu/facultypub/675

Conner, M.E. (2015). Judicial educator: change leader. In Journal of the International Organization for Judicial Training (3) Carmi, A., Armytage, L., McDowell, A., Campbell, C. (Eds.) (2015) issue 3, pp.6-15. National Center for State Courts.

Cotterrell, R. (1998). Why must legal ideas be interpreted sociologically. Journal of Law and Society, 25(2)

Cox, D.R., (2014).A short review of bad judges, and good.Green Bag 2D, 17, 475479.http://greenbag.org

Crowell, M. (1988).Basics of judicial immunity.University of North Carolina School of Government.https://www.sog.unc.edu/resources/legal-summaries/basics-judicial-i... 


\section{International Journal of Social Science and Economic Research}

ISSN: $2455-8834$

Volume:05, Issue:08 "August 2020"

D’Amato, A. (1977). Can/should computers replace judges? Georgia Law Review, 11, 11-36

Daly, M.C. (1999). Some thoughts on the differences in criminal trials in civil and common law legal systems.Journal of the Institute for the Study of Legal Ethics 2(6), 65

Davis, W. (2019).Bullying from the bench. A wave of high- profile has put scrutiny on judges. $A B A$ Journal, https://www.abajournal.com/magazine/article/bullying-from-the-bench

Dechalert, A. (2019). I never intended for a judge to be my role model in life. Medium.

https://medium.com/prototyping-a-year/i-never-intended-for-judge...

Devlin.(1976). Judges and lawmakers.Modern Law Review, 39(1), 1-16

Devlin, P. (1979). The judge. Oxford University Press

Devlin.(1965). Mill on liberty in morals.The University of Chicago Law Review, 32(2), 215

Dworkin, G. (1962). Stare decisis in the House of Lords. Modern Law RW. 25, 163-178 https://www.jstor.org/stable/1093592?seq=1

Edwards, H.T. (1984). Public misperceptions concerning the "politics" of judging: dispelling some myths about the D.C. Circuit. U. Colo. L. Rev. 56 (4) 619

Ehrlich E. (1903). Freierechtsfindung und FreieRechtswissenschaft: Vortrag, gehalten in der juristischenGesellschaft in Wien am. CL Hirschfeld. Trans. Bruncken, E. as "Judicial freedom of decisions: its principles and objects", in Science of Legal Method: selected essays by various authors, tr. Bruncken, E. \& and Register, L.B. 49-84, (1969) New York: A.M. Kelley

Ehrlich, E. (1975). Fundamental principles of sociology of law. Arno Press, digitized 2011

Ehrlich, E., \& Isaacs, N. (1922).The sociology of law. Harvard Law Review. 36(2), 130145 https://www.jstor.org/stable/1329737

Eldergill, A.(2015). Compassion and the law: a judicial perspective. Elder LJ, 268

Epstein, L. (2016). Some thoughts on the study of judicial behavior.Wm\& Mary L. Rev.57(6), 3, 2017

Epstein, L. \& Knight, J (2017).The choice justice make. Congressional Quarterly Inc.

Finnis, J. (2019). The unconstitutionality of the Supreme Court's Prorogation judgment.Policy Exchange.https://policyexchange.org

Flango, V.E. (2011). Is procedural fairness applicable to all courts? Court Review: The Journal of the American Judges Association. 47, 92.

Flango, V.E., Wenner, L.M.S., Wenner, M.W. (1975). The concept of judicial role: a methodological note. American Journal of Political Science, 277-289

Frailing, K. (2016). The achievements of Specialty Courts in the United States.Scholars Strategy Network.https://scholars.org/contribution/achievements-specialty-courts-unitedsta... 


\section{International Journal of Social Science and Economic Research}

ISSN: $2455-8834$

Volume:05, Issue:08 "August 2020"

Frank, J. (1930). Law and the modern mind.Bretano's Publishers.

Frankfurter, F. (1939).Mr. Justice Cardozo and public law.The Yale Law Journal, 48(3), 458-488

Gloppen, S. (2013).Courts, corruption and judicial independence.In Corruption, grabbing and development.(2013) Søreide, T. \& Williams, A. (Eds.), Chapter 5, pp68-79. Edward Elgar Publishing

Goldbach, T.S. (2016). From the court to the classroom. Cornell Int'l LJ, 49, 617

Goldbach, T.S. (2016). From the court to the classroom: judges' work in International Judicial Education. Cornel International Law Journal, 49, 617

Hanna, J. (1957). The role of precedent in judicial decisions. Vill. L. Rev. 2(3), 367

Guggenheim, M. \& Hertz, R. (2016). Selling kids short: how "Rights for Kids" turned into "Kids for Cash". Temple Law Review, 88, 653

Hanson, E. (2002). The changing role of the judge and its implications. Court Review: The Journal of American Judges Association, 38(4), 10

Harding, A. (2017). The fundamentals of constitutional courts.International Institute for Democracy and Electoral Assistance(IDEA) Constitution Brief. https://www.idea.int.

Hart, H.L.A., \& Hart, H.L.A. (2012).The concept of law.Oxford University Press.

Heinsz, T.J. (1996). A tribute to Judge Elwood L. Thomas.Missouri Law Review, 61(1)

Campbell, J.C.B. (1856). Atrocious judges: lives of judges infamous as tools of tyrants and instruments of oppression. Miller, Orton \& Mulligan.

Hoffman, B. (2017). Perfectly wrong: why perfection can destroy your motivation. Psychology Today.

https://www-psychologytodaycom.cdn.ampproject.org/v/s/www.psychologytoday.com/us/bl...

Holman, B., Kanodia, K., Moussako, A.,Plesh, R., Waggeh, F., Zouai, M. (2019). Access to justice in Gambia. University of Pennsylvania Law School https://www.law.upenn.edu/lie/nes/9436-access-tojustice-in-the-gambiahttps://www.rd.com/culture/bad-judges

Ifill, S.A. (2000). Racial diversity on the bench: beyond role models and public confidence. Wash. \& Lee L. Rev., 57, 405

International Commission of Jurists (2007).International principles on the independence and accountability of judges, lawyers, and prosecutors-a practitioners guide, No.1. Author

Joy, P.A. (2000). A professionalism creed for judges: leading by example SCL Rev., 52, 667

Judge, K. (2019). Judges and judgment: in praise of instigators. The University of Chicago Law Review, 86, 1077-1096

Kapiszewski, D., Silverstein, G., Kagan, R.A. (Eds.). (2013). Consequential courts: judicial roles in global perspective. Cambridge University Press 


\section{International Journal of Social Science and Economic Research}

ISSN: $2455-8834$

Volume:05, Issue:08 "August 2020"

Kirby (1998).Attacks on judges- a universal phenomenon.Speech delivered at the American Bar Association Section of Litigation Winter Leadership meeting Maui, Hawaii $5^{\text {th }}$ January 1998 https://www.hcourt.gov.au/assets/publications/speeches/former-justices/kirb..

Koppensteiner, N. (2020). A crack in everything. In. Brantmeier, E.J., \& McKenna, M.K.(Eds.). The pedagogy of vulnerability (2020).IAP.Chapter 7.

https://books.google.gm/books?id=_qPbDwAAQBAJ\&pg=PR7\&source=gbs_se...

Kozinski, A. (2004). The real issues of judicial ethics.Hofstra Law Rev. 32(4), 1095

Kraus Whitbourne, S. (2013). We all need role models to motivate and inspire us. Psychology Today.

https://wwwpsychologytodaycomcdn.ampproject.org/v/s/www.psychologytoday.com/us/blog/fulfillmentat-anyage//201311/w...

Kyriakides, N. (2016). Judicial discretion and contempt power: two elements of equity that would benefit the EAPO and the future EU-wide provisional and protective measures.

Doctoral thesis, University of Oxford https://ora.ox.ac.uk/objects/unid:91c8379a-252c-475c-995d$\underline{7 d 7} \ldots$

Landfried, C. (2019). Judicial power: how constitutional courts affect political transformations. Cambridge University Press

Law, D.S. (2009). A theory of judicial power and judicial review.The Georgetown Law Journal, 97, 723

Lewis, T. E. (1990). The history of judicial precedent. $L Q$ Rev., 46, 341.

Logan, C. (2017) Afro barometer Policy Paper no. 39 (2017). Ambitious SDG goal confronts challenging realities: access to justice is still elusive for many Africans. Afrobarometer.http://afrobarometer.org/publications/pp39-access-to-ju...

Mance, J. (2017). The role of judges in a representative democracy.Lecture given during the Judicial Committee of the Privy Council's Fourth Sitting in the Bahamas.

https://www.supremecourt.uk

Martin, K.(2020). Violent offender reduced to tears as judge spares him penitentiary. Calgary Herald.https://calgaryherald.com/news/crime/violent-offender-reduced-to-tears-asjudge...

Martineau, R.J. (1981). Disciplining judges for non official conduct: a survey and critique of the law.University of Baltimore law Review 10 (2), 2.

McLachlin, B. (2012). The relationship between the courts and the media.Remarks of the Right Honourable Beverley McLachlin, P.C. Chief Justice of Canada https://www.scc.csc.ca/judge-juges/spedis/bm-2012-01-31-... 


\section{International Journal of Social Science and Economic Research}

ISSN: $2455-8834$

Volume:05, Issue:08 "August 2020"

Morgenroth, T., Ryan, M.K., Peters, K. (2015). The motivational theory of role modeling: how role models influence role aspirants' goals. Review of General Psychology (advance online publication) https://dx.doi.org/10.1037/gpr0000059

Mullerat, R. (2008).US and EU legal professions: two lawyers separated by the same justice. Common law and civil law procedure compared. Jean Monnet/ Robert Schuman Paper series 8(4).https://www.aei.pitt.edu >MulleratEU_US ...

Nabaneh, S. (2018).The need for an independent Gambian judiciary.Law Hub Gambia.https://www.lawhubgambia.com/lawhug-net/independent-gambian-judiciary

Nakad-Westrate, H.W.R (Henriëtte)., van den Herik, H.J.(Jaap)., Jongbloed, A.W. (Ton)., Salem, A. B. M. (2015). The rise of the robotic judge in modern court proceedings.ICT 2015

The $7^{\text {th }}$ International Conference on Information Technology.

Doi:10.15849/icit.2015.0009

Nava, M. (2008). The servant of all: humility, humanity, and judicial diversity. Golden Gate U.L. Rev. $38(2), 175-194$

Nelken, D. (2008). Eugene Ehrlich, living law, and plural legalities.Theoretical Inquiries in Law, 9(2), 443

Neuberger, D. (2012). No judgment- no justice. First Annual BAIL II Lecture.https://www.iclr.co.uk/ https://www.supremecourt.uk

Nichol, D. (2019). Supreme Court against the people.UK Constitutional Law Association.https://ukconstitutionallaw.org/2019/09/25/danny-nichol-supreme-courtagainst-th...

Noble, R.K. (1993).A tribute to a scholar, a wise jurist, and a role model.Pennsylvania Law Review, 142,531

Pacht, A.R. (1984). Reflections on perfection.American Psychologist, 39(4), 386-390

Palmer, B. (2009). Do judges really have to follow precedent? Slate magazine.https://slatecom.cdn.ampproject.org/v/s/slate.com/news-and-politics/2009/07/wha...

Posner, R.A. (2006). The role of the judge in the twenty-first century.Boston University Law Review, 1049

Posner, R.A. (2013). Reflections on judging. Harvard University Press

Pound C.W. (1922).The judicial power.Harvard Law Review, 35(7), 787-796

Pound (1906). The causes of popular dissatisfaction with the administration of justice.Presented at the annual convention of the American Bar Association

Pound, R. (1910). Law in books and law in action.Am. L. Re., 44, 12.

Pound, R. (1921). A theory of social interests.15 AM Socio L. Soc. Pub.42-43 


\section{International Journal of Social Science and Economic Research}

ISSN: $2455-8834$

Volume:05, Issue:08 "August 2020"

Pound, R. (1930) An introduction to the philosophy of law

Powell, L.F. Jr. (1990). Stare decisis and judicial restraint. Wash \& Lee L. Rev. 47(2), 281

Přibón̆, J. (2017). A sociology of legal distinctions: introducing contemporary interpretations of classic socio-legal concepts. Journal of Law and Society, 44, S1-S18

Ray, D.E. (2010). The seven important roles judges play in our society. The University of Toledo College of Law Transcript, 24-25

Reid. (1972). The judge as lawmaker. Journal of the Society of Public Teachers of Law, 12, 22

Resnick, J. (1988). On the bias: feminist reconsiderations of the aspiration for judges.

Southern California Law Review 61, 1877

Reuschlein, H.G. (1941). Roscoe Pound- The Judge.U. Pa. L. Rev., 90, 292

Richardson, G.L. (2016). Black robe fever. Jewell Press

Robbins-Tiscione, K. K. (2002). The inside scoop: what federal judges really think about the way lawyers write. The Journal of Legal Writing Institute, 8, 257-284

Rose, R.W. (1999). A tribute to Judge A. Leon Higginbotham Jr.: Farewell to a Giant. Roger Williams University Law Review 4(2), 387

Scheb, J.M., Ungs, T.D., Hayes, A.L. (1989). Judicial role orientations, attitudes and decision making: a research note. Western Political Quarterly, 42(3), 427-439Schwehn, M. (Ed.) (2000).Everyone a teacher. University of Notre Dame Press

Senghore, A.A. (2010). The judiciary in governance in The Gambia: the quest for autonomy under the second republic. Journal of Third World Studies, 27(2), 215-248 https://www.lawhubgambia.com/lawhug-net/independent-gambian-judiciary

Shanahan, E. (2019). Judge obstructed justice in $\$ 10$ million corruption case, U.S. says. The New York Times.

https://wwwnytimescom.cdn.ampproject.org/v/s/www.nytimes.com/2019/10/11/nyregion/brooklynsupremecourt-judge-syl...

Smith, M.K. (2019). What is teaching? A definition and discussion.Infed.https://infed.org/mobi/what-is teaching/

Solum, L.B. (1988). The virtues and vices of a judge: an Aristotelian guide to judicial selection. S. Cal. L. Rev., 1735

Stein, R. (2007). Causes of popular dissatisfaction with the administration of justice in the twenty-first century.Hamline Law Review 30(3), 499 


\section{International Journal of Social Science and Economic Research}

ISSN: $2455-8834$

Volume:05, Issue:08 "August 2020"

Stengel, T.M. (2012). Absolute judicial immunity makes absolutely no sense: an argument for an exception to judicial immunity. Temple Law Review, 84, 1072

Stewart, C.E. (2003). Abuse of power \& judicial misconduct: a reflection on contemporary ethical issues facing judges. U. St. Thomas L.J. 464

Stewart, C.E. (2003). Abuse of power \& judicial misconduct: a reflection on contemporary ethical issues facing judges. University of St. Thomas Law Journal, 1 (1), 464

Teach.com (n.d.). Teachers are role models. https://teach.com/what/teachers-are-rolemodels/

Teach.com. (n.d.). What does teachers do? https://www.teach.com/what/

Tetley, W. (2000). Mixed jurisdictions: common law v civil law (codified and uncodified). Louisiana Law Review, 60(3), 677

Tetley, W. (2000). Mixed jurisdictions: common law v. civil law (codified and uncodified). Louisiana Law Review, 60(3), 677

Thompson, D. (1958). Judicial immunity and the protection of justices.The Mod. Law Rev., 21, 517

Uspanov, Z.T. \&Turabayeva, D.S. (2016).Psychological peculiarities of judge professional activity and decision- making.International Journal of Environmental \& Science Education, 11(3), 5845-5856

Van den Herik, H.J. (1991). Can computers judge court cases? (Kunnen Computers Rechtspreken?)Inaugural address Leiden $21^{\text {st }}$ June 1991, Arnheim: Gouda Quint 1991

Van Puymbroek, R. V. (Ed.). (2001). Comprehensive legal and judicial development: towards an agenda for a just and equitable society in the $21^{\text {st }}$ century. The World Bank

Vohs, K.D., Aaeker, J.L, Catapano, R. (2018). Its not going to be that fun: negative experiences can add meaning to life. Current Opinion in Psychology, 26, 11-14. https://doi.org/10.1016/j.copysyc.2018.04.014

Vong, D. (1984). Binding precedent and English judicial law-making.Jura Falconis, 1985, 318-346

Vultaggio, M. (2018). 16 Inspirational Stephen Hawkings Quotes about life, the universe, and more. Newsweek.https://www.newsweek.com/stephen-hawking-quote-life-universealiens-dead-8...

Weinstein, J.B. (2004). Everyday is a good day for a judge to lay down his professional life for justice. Fordham Urban Law Journal 32(1) 6, 101

Weisenberg, W.K. (2018). Why our judges and courts are important. American Bar Association Journal.https://www.abajournal.com/news/article/why our judges and co...

Whisner, M. (2004).When judges scold lawyers.Law Library Journal, 96(3), 557

Williams, G. (2013). A short book of bad judges.Wildy, Simmonds and Hill Publishing 
International Journal of Social Science and Economic Research

ISSN: 2455-8834

Volume:05, Issue:08 "August 2020"

Wilson, B. (1990). Will women judges really make a difference? Osgoode Hall Law Journal, 28(3), 507

World Justice Project (2019). Global insights on access to justice. Author https://worldjusticeproject.org/our-work/publications/special-reports/global-insights

\section{Cases cited}

Ambard $\mathrm{v}$ AG of Trinidad and Tobago [1936] UKPC 16 https://www.casemine.com/judgement/in/56b49624607dba348f016f25 Arundhati Ashok Walavalkar v State of Maharashtra \&Anor [2011] INSC 45

Brown v Allen (1953) 344 U.S. 443

Chandler v Crane Christmas \& Co [1951] 2 KB 164, 178

Close v Steel Co. of Wales Ltd [1961] 3 W.L.R. 319;

Derry v Peek [1889]. UKHL 1

English v Emery Reimbold\&Strick Ltd. [2002] EWCA Civ 605 Flannery v Halifax Estate $\begin{array}{lllllll}\text { Agencies } & \text { Ltd } & {[2000]} & 1 & \text { ALL } & \text { ER } & 373\end{array}$ https://www.bailii.org/ew/cases/EWCA/Civ/1999/811.html Hedley Byrne and Co Ltd v Heller and Partners Ltd [1964] AC 465.

London Street Tramways v London County Council [1898] AC 375

Miller v Minister of Pensions (1947) 3 ALL ER, 372

Packer v Packer (1953) 2 ALL ER. 127, 129

R (on the application of Miller) v The Prime Minister [2019] UKSC 41

R v Sussex Exparte McCarthy [1924]. 1KB, 256

Re Morrissey (1974).366 Mass.11

Simetra Global Assets Ltd \&Anor v Ikon Finance Ltd \&Ors [2019] EWCA Civ. 1413

Spicer v Spicer (1791) 79 ER 451

Woolmington v DPP [1935] UKHL 1 
International Journal of Social Science and Economic Research

ISSN: 2455-8834

Volume:05, Issue:08 "August 2020"

YaKumbaJaiteh v Clerk of the National Assembly \&Ors, S.C. No. 001/2019 Young v Bristol Aeroplane Company Limited [1944] 1KB 718

\section{Legal instruments \& UN documents}

The Constitution of Ghana (1992)

The Constitution of Kenya (2010)

The Constitution of South Africa (1996)

The Constitution of The Gambia 1997

The Constitution of the United States of America (1787) Final Draft Constitution (of The Gambia) 2020. https://crc220.orghttps://crc220.org

Judges (supplementary code of conduct) Act (2009). Cap 7 Laws of The Gambia, Vol.2 UNDP Practice Note on access to justice 2015.

https://www.undp.org/content/undp/en/home/librarypage/democratic-governance...

UNDP Sustainable Development Goals.

https://www.undp.org/content/undp/en/home/sustainable-deve... 